\section{Nyttig og lettlest om spiseforstyrrelser}

Anne Røer

\section{Spiseforstyrrelser}

Symptomforståelse og behandlingsstrategier. 2. utg. 168 s, tab, ill. Oslo: Gyldendal Akademisk 2009. Pris NOK 275

ISBN 978-82-05-39245-8

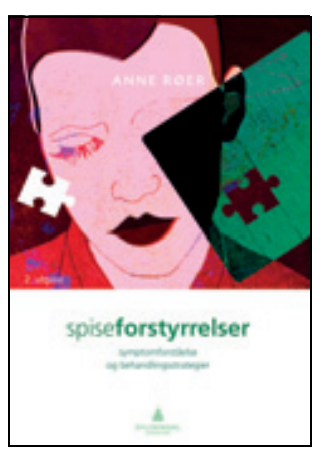

Dette er en av få fagbøker på norsk om spiseforstyrrelser. Denne andre utgaven er utvidet med nyere kunnskap om nevropsykologiske forhold, flerfamiliegruppebehandling ved anoreksi og et kapittel om tverrfaglig samarbeid

og behandlingsplan. Målgruppen er studenter og helsepersonell.

Forfatteren er psykologspesialist med lang klinisk erfaring med spiseforstyrrelser, hovedsakelig fra privat praksis og barnemedisinsk avdeling. Hun har sine faglige røtter innen familieterapi og kognitiv terapi, som er anerkjente behandlingstilnærminger ved spiseforstyrrelser. Første del omhandler ulike tilnærminger til å forstå spiseforstyrrelser, og andre del dreier seg om behandling. Forfatteren presenterer stoffet på en oversiktlig og pedagogisk måte. Alt er rikelig illustrert med kliniske eksempler, noe som letter forståelsen og bidrar til å gjøre stoffet engasjerende.

Forfatteren lykkes godt med å beskrive og integrere ulike forståelsesmåter og behandlingstilnærminger. I fremstillingen av familieforståelse og familieterapi ved spiseforstyrrelser omtales både de tidligste retningene, som til en viss grad ble utviklet nettopp $i$ arbeidet med unge med anoreksi, og nyere tilnærminger med søkelyset rettet mot språk, narrativer, eksternalisering, tilknytningsteori og foreldretrening. Her kunne hun kanskje med fordel også nevnt Maudsley-modellen, som er en mye brukt manualisert familieterapitilnærming for unge med anoreksi (1).

Det foreligger god dokumentasjon for at kognitiv terapi er effektivt ved spiseforstyrrelser, særlig for voksne med bulimi, og kapitlet om kognitiv terapi gir en god introduksjon til dette fagområdet. Det er positivt at man fokuserer på samarbeid med familien innen en kognitiv behandlingstilnærming, noe som kan være spesielt relevant for unge pasienter. Det er også nyttig at man diskuterer den høye samsykeligheten mellom spiseforstyrrelser og angstlidelser, og indikasjoner for kognitiv terapi for å overkomme samtidige angstlidelser, spesielt. Andre komorbide psykiske tilstander omtaler man også, men det er naturlig nok begrenset hvor omfattende dette kan behandles i en såpass kortfattet bok.

I det nye kapitlet om tverrfaglig samarbeid og behandlingsplan fokuserer man særlig på oppfølging fra fastlegen og på samarbeid med skolen. Etter min mening burde spesialisthelsetjenestens oppgaver og ansvar for alvorlige spiseforstyrrelser, og kriterier for henvisning til spesialisthelsetjenesten, kommet tydeligere frem.

I omtalen av taushetsplikt burde det vært opplyst om at helsepersonell uten hinder av taushetsplikten kan, og bør, informere foreldre til unge opptil 18 år om forhold de må vite for å ivareta sitt foreldreansvar, da dette ofte vil være en aktuell problemstilling ved alvorlige spiseforstyrrelser hos unge. Et par små detaljer i dette kapitlet er noe forvirrende, for eksempel vedrørende måling av beinmasse samt en kasuistikk der det ser ut som en pasient med vekt «innenfor normalområdet» har BMI 14.

Jeg opplever boken som inspirerende og matnyttig, særlig med henblikk på de psykologiske aspektene av symptomforståelse og behandling. Jeg vil anbefale den som en innføring til fagområdet, og som supplement til kliniske retningslinjer og større lærebøker.

\section{Inger Halvorsen}

Regional avdeling for spiseforstyrrelser Oslo universitetssykehus, Ullevål

\section{Litteratur \\ 1. Lock J, Le Grange D, Agras WS et al. Treatment manual for anorexia nervosa: a family-based approach. New York, NY: Guilford Press, 2001}

\section{Ambisiøst om kompliserte sammenhenger}

Jane Ogden

The psychology of eating

From healthy to disordered behavior. 2. utg.

392 s, ill. Chichester: Wiley-Blackwell, 2010.

Pris GBP 20

ISBN 978-1-4051-9120-3

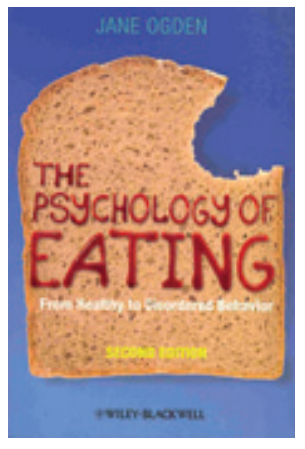

Vekt- og spiseproblemer er en betydelig utfordring $i$ et folkehelseperspektiv, og med denne boken har forfatteren som mål å gi en bred oversikt over forskningslitteraturen som dekker spekteret av spiseatferd, fra sunn spising via kroppsmisnøye og slanking til spiseforstyrrelser og fedme. Målgruppen er fagpersoner som interesserer seg for ulike aspekter innenfor dette området, og målet er å utvikle en integrert modell for sammenhengen mellom ulike faktorer som kan føre til utvikling av forstyrret spiseatferd og vektproblemer.

Man kan oppleve tittelen som noe misvisende, for selv om temaet er spisingens psykologi, presenterer forfatteren forskning fra mange ulike fagområder. Forhold som genetikk, nevrobiologi og ulike sosiokulturelle faktorer er viet stor plass.

Med referanse til 985 artikler er spennvidden i den forskningen som forfatteren presenterer, stor, og det kan synes ambisiøst å skulle dekke alt fra sunt kosthold til behandling av spiseforstyrrelser innenfor to permer. Dette er derfor ikke en lærebok i vanlig forstand, men de ulike kapitlene kan hver for seg og sammen bidra til en bedre forståelse for den komplekse sammenhengen mellom ulike faktorer, deriblant slanking, som fører til så vidt ulike sykdommer som anoreksi og fedme.

Det er en utfordring at så få velger å følge råd og retningslinjer fra helsemyndighetene. Årsaken til utviklingen av et usunt spisemønster er kompleks, og heller ikke denne boken kan gi en enkel oppskrift på forebygging av fedme, vårt kanskje største folkehelseproblem.

Temaet om legers antakelser omkring fedme fanget min interesse spesielt. Her refererer forfatteren til studier som konkluderer med at leger viser lite entusiasme i forhold til å jobbe med vektreduksjon hos sine pasienter. Mange mener at dette ikke er innenfor deres fagfelt, og de har liten tro på effekten av ulike behandlingsmetoder. Og mens allmennpraktikere tenderer til å mene at fedme skyldes psykologiske og atferdsmessige faktorer, har befolkningen generelt en mer biologisk forklaringsmodell. Kan legers manglende faglighet $\mathrm{i}$ forhold til fedmepasienter være et hinder for at denne pasientgruppen får adekvat behandling og oppfølging?

For å kunne fordøye alt i denne boken, må den leses i passe porsjoner. Da kan den gi opphav til nyttige refleksjoner omkring sammenhengen mellom spiseatferd, slanking og utvikling av sykdom. Jeg oppfatter ikke Ogdens modell som spesielt ny og spennende, og den er bare et steg på veien mot en integrert modell som vi kan benytte for å forebygge disse problemene. Men litteraturgjennomgangen og noen av diskusjonene gir absolutt grunnlag for nye tanker om kompliserte sammenhenger.

\section{Sigrid Bjørnelv}

Psykiatrisk klinikk

Sykehuset Levanger 